\title{
Jacopo Tintoretto i Vettore Trincavella - malarz i lekarz w bractwie św. Rocha w Wenecji
}

Słowa kluczowe: Tintoretto; Trincavello; medycyna renesansowa; bractwo św. Rocha

Wśród nielicznych przykładów szesnastowiecznych przedstawień szpitalnego wnętrza na szczególną uwagę zasługuje obraz ukazujący św. Rocha uzdrawiającego lub, jak uważają inni, jedynie wizytującego chorych w lazarecie. Wyszedł on spod pędzla Jacopo Robustiego, zwanego Tintorettem (1519?-1594)². Olej na płótnie mierzący ponad sześć metrów szerokości i ponad trzy metry wysokości przeznaczony został do prezbiterium kościoła św. Rocha w Wenecji, gdzie znajduje się do dzisiaj $^{3}$. Nie jest to jednak obraz ołtarzowy. Zgodnie z typowym weneckim zwyczajem umieszczono go na bocznej ścianie prezbiterium ${ }^{4}$.

${ }^{1}$ Instytut Kulturoznawstwa, Uniwersytet Marii Curie-Skłodowskiej, Lublin, e-mail: rybalte@poczta.umcs.lublin.pl, ORCID: 0000-0002-2628-5038. Autorka dziękuje dr Marii Ołdakowskiej za językową korektę niniejszego tekstu.

2 S.M. Rinaldi, Le immagini della peste nella cultura figurative veneziana, [w:] Venezia e la peste 1348-1797, Venezia 1979, s. 209-224; por. M.E. Massimi, Jacopo Tintoretto e i confratelli della Scuola Grande di San Rocco. Strategie culturali e commitenza artistica, ,Venezia Cinquecento” 1995, a. 5, n. 9, s. 65.

3 Wymiary podane za kartą katalogową: P. Rossi, San Rocco risana gli appestati, [w:] Tintoretto. Le opere sacre e profane, R. Palluchini, P. Rossi (red.), Milano 1982, vol. 1, s. 158. Pisownię imienia i nazwiska Vittore Trincavelli przyjęto za G. Ongaro, hasło Trincavelli Vittore (Venezia 1496-ivi, 21.08.1568), [w:] Clatiores. Dizionario biografico dei docenti e degli studenti dell'Università di Padova, P. Del Negro (red.), Padova 2015, s. 328-329.

${ }^{4}$ M. Matile, «Quadri laterali» im sakralen Kontext. Studien und Materialien zur Historienmalerei in venezianischen Kirchen und Kapellen des Cinquecento, München 
Historycy sztuki podkreślają wyjątkowy sposób, w jaki artysta oddał szpitalne wnętrze, nadając mu realistyczny charakter, którego brakuje nawet w późniejszych przedstawieniach podobnych tematów ${ }^{5}$. Celem niniejszego tekstu jest zwrócenie uwagi na niektóre elementy ikonografii przedstawienia, jakie dotychczas nie zostały poddane dyskusji w literaturze przedmiotu, a mogą mieć związek z bezpośrednim kontekstem historycznym powstania dzieła.

Pierwszy biograf Tintoretta Carlo Ridolfi (1594-1658) pisał, że jest to obraz:

św. Rocha w szpitalu, który znakiem krzyża uzdrawia pewnego zadżumionego, a ten podnosi nogę, pokazując ranę. Reszta tego szpitala pełna jest kobiet i chorych mężczyzn. Niektórzy stoją na ławach i odwiązuja sobie rany, inni, wycieńczeni, leżą na ziemi w tak niezwykłych skrótach perspektywicznych, iż stopy wydają się im wystawać z płótna; niektórzy starcy podtrzymywani są przez młodych, i kobiety podnoszące się z łóżka, [wszyscy] wydają się polecać pobożności Świętego. To dzieło znane jest ze względu na niezwykłość swej kompozycji, ponieważ wszystkie jej elementy zostały potraktowane w sposób odpowiedni dla tego miejsca, tak że wzbudzają w poruszonych duszach współczucie, czy to ze względu na kompozycję, czy też kolor, gdyż wydają się stworzone nie barwą, ale jakby były żywymi ciałami [...] Wszyscy, którzy właściwie rozpatrują [sztukę - przyp. ER] muszą się zgodzić, że trudno o bardziej erudycyjne dzieło ${ }^{6}$.

Zatem już współcześni Tintoretta cenili jego obraz za naturalne, ale jednocześnie bardzo urozmaicone przedstawienie ludzkiego ciała. Jednocześnie obnażeni chorzy stali się jedynym źródłem światła w obrazie, który został wykonany w konwencji nokturnu. Oglądający obraz doświadcza sytuacji granicznej między światłem życia, kruchym i ułomnym z perspektywy ludzkiej cielesności a mrokiem śmierci. W tle obrazu zaledwie widoczne postacie wynoszą ciało zmarłego. Kontrast, który pojawia się między obnażonymi postaciami chorych i scenerią nokturnu, pozwolił artyście na wykazanie się wirtuozerią

1997; na temat specjalizowania się Tintoretta w przedstawieniach umieszczanych na bocznych ścianach tzw. laterali zob.: tenże, «Quadri laterali», ovvero conseguenza di una collocazione ingrata. Sui dipinti di storie sacre nell'opera di Jacopo Tintoretto, „Venezia Cinquecento” 1996, a. 6, n. 12, s. 151-206.

${ }^{5}$ S.M. Rinaldi, dz. cyt., s. 220.

${ }^{6}$ Tłumaczenie, jeżeli nie zaznaczono inaczej, zostało wykonane przez Ewę Rybałt. Dla większej przejrzystości prezentowanego tekstu złożony termin disegno przetłumaczono jako kompozycja. Zob. C. Ridolfi, Le maraviglie d'arte ovvero le vite degli illustri Pittori Veneti e dello stato, Venetia 1648 (reprint: Roma 1965), vol. II, s. 17-18. 
kompozycyjną nie tylko w prezentacji ludzkiej anatomii, ale także w ukryciu niektórych elementów przedstawienia.

I tak, np. sam protagonista przedstawienia - św. Roch - ukazany jest niejako od tyłu w typowym dla siebie, ciemnym ubraniu pielgrzyma. Jedynie niepełny profil jego twarzy został rozświetlony aureolą. Prawą dłoń św. Roch wyciąga ku ranie na udzie chorego. Gest świętego wydaje się bardzo podobny do tego, jaki wykonuje Chrystus w przedstawieniu wydarzenia znad sadzawki Betesda (J. 5, 1-19), które Tintoretto namalował w 1559 r. również dla kościoła św. Rocha. Istnieje jednak niezwykła, subtelna, zaledwie dostrzegalna różnica w układzie palców prawej dłoni św. Rocha i Chrystusa. Jezus jednoznacznie wykonuje znak błogosławieństwa, pochylając się nad chorymi. Widzimy to dokładnie, ponieważ sylwetka Jezusa została przedstawiona frontalnie. Natomiast układ palców prawej dłoni św. Rocha, ukazanego w trzech czwartych, nie pozwala na tak jednoznaczną interpretację. Trudno jednak uznać, że gesty obu postaci są identyczne. Tintoretto należał do artystów, którzy traktowali przedstawienia gestu w obrazie ze szczególną pieczołowitością̧. Nieprzypadkowo zatem gest św. Rocha został niejako ukryty, chociaż sama dłoń znajduje się w centrum obrazu. Być może trudności w interpretacji znaczenia omawianego gestu można powiązać $\mathrm{z}$ dyskusją odnoszącą się do problemu świętości, która odżyła w czasie Soboru Trydenckiego (1545-1563).

W połowie XVI w. kryzys kultu świętych, ale także rozumienia cudów, w tym cudownych wizerunków, wywołany został nie tylko przez protestanckich reformatorów, ale także przez katolickich humanistów $^{8}$. Rozwinięcie tego zagadnienia wykraczałoby poza ramy niniejszej prezentacji. Natomiast warto zaznaczyć, że w samej Wenecji hierarchowie katoliccy usiłowali zapobiegać nadużyciom kultu świętości, gdyż graniczył on często z praktykami magicznymi ${ }^{9}$. Tendencje, o jakich mowa, miały miejsce m.in. w bractwie św. Rocha. Cześć, którą oddawano obrazowi namalowanemu przez Tycjana (1480-1576), przedstawiającemu Chrystusa niosącego krzyż, nosiła znamiona praktyk magicznych ${ }^{10}$. Obraz przyczyniał się do wzbogacenia konfraterni, ale pobożne praktyki związane z przedstawieniem Tycjana mogły być

${ }^{7}$ E. Dal Pozzolo, Il gesto di Tintoretto, [w:] tenże, Colori d'amore. Parole, gesti e carezze nella pittura veneziana del Cinquecento, Treviso 2008, s. 161-166.

${ }^{8}$ S. Cavalotto, Santi nella riforma. Da Erasmo a Lutero, Roma 2009.

9 A. Prosperi, Gian Battista Bascio e la predicazione dei romiti alla metà del '500, „Bolletino della Societa di Studi Valdesi” 1975, no. 138, s. 69-79.

${ }^{10}$ M. Holmes, The Miraculous Image in Renaissance Florence, New Haven 2013, s. 259 . 
kwestionowane przez niektórych gwardianów bractwa ${ }^{11}$. Być może zatem Tintoretto, który jak powszechnie wiadomo, był jednym z najbardziej zagorzałych rywali Tycjana, pragnął, aby jego obrazy pełniły inne funkcje niż dzieła starszego mistrza ${ }^{12}$.

Augusto Gentili, dokonując pogłębionej refleksji nad sposobem przedstawiania cudów, zwłaszcza w obrazach Tintoretta, podkreślał, że artysta zmierzał do ukazania cudu uzdrowienia jako aktu jednostkowego, który nie wynika $\mathrm{z}$ mechanicznego powielania rytualnych czynności przez wiernych ani też przez samego świętego ${ }^{13}$. Stąd też św. Roch w lazarecie Tintoretta kieruje się tylko ku jednemu chore$\mathrm{mu}$, chociaż wielu innych spogląda $\mathrm{z}$ nadzieją $\mathrm{w}$ jego stronę.

Można przypuścić jednak, że kluczowymi dla zrozumienia aktualnych treści przedstawienia są dwie postacie kryjące się w cieniu św. Rocha. Wraz z głównym bohaterem tworzą one rodzaj lekarskiego konsylium. Jedna $\mathrm{z}$ nich, stojąc frontalnie do widza u wezgłowia chorego, z przejęciem pochyla się nad zaczerwienioną raną ofiary epidemii i bezradnie rozkłada ręce. Gest zawieszonej w powietrzu dłoni kontrastuje ze zdecydowanym wyciągnięciem ku ranie prawej ręki świętego. Twarz tej osoby jest zaledwie widoczna. Tintoretto bardzo często posługiwał się takim sposobem portretowania, który pozwalał raczej domyślać się tożsamości ukazanej postaci niż ją identyfikować ${ }^{14}$. Korporacyjny mecenat bractw nie sprzyjał uwydatnianiu indywidualnych rysów poszczególnych jednostek ${ }^{15}$. Również strój tajemniczej postaci u wezgłowia chorego niewiele nam o niej mówi.

${ }^{11}$ Warto np. zwrócić uwagę, że z testamentu Melio da Cortona wynika, że pragnął, aby inny obraz Tycjana, Zwiastowanie, który znajdował się w jego posiadaniu, trafił po jego śmierci do bractwa św. Rocha. Miał świadomość jednak, że nie wszyscy gwardianie mogą chcieć przyjąć dar. W przypadku odrzucenia przez bractwo obraz miał znaleźć się w kościele kamedułów z San Michele in Isola. Jest to szczegół tym bardziej interesujący, że statuty konfraterni nie pozwalały na odrzucanie darowizny. Por. Archivio di Stato Venezia, Notarile Testamenti, t. 250, f. 49.

12 M. di Monte, La morte è bella: il martirio nella pittura di Tiziano, Tintoretto, Veronese, "Venezia Cinquecento" 1999, no. 17, s. 91-179; M. Falomir, Tintoretto y Tiziano, [w:] Jacopo Tintoretto, Actas del congreso internacional, M. Falomir (red.), Madrid 2009, s. 66-71; F. Ilchman, Venetian Painting in an Age of Rivals, [w:] Titian, Tintoretto, Veronese. Rivals in Renaissance Venice [kat. wyst.], F. Ilchman (red.), London 2009, s. 21-38.

13 A. Gentili, La bilancia dell'arcangelo.Vedere i dettagli nella pittura veneziana del Cinquecento, Roma 2009, s. 199-214 [Vedere i miracoli. Politiche della guarigione in Tintoretto e Veronese].

${ }^{14} \mathrm{Na}$ temat profil perdu u Tintoretta zob.: C. Gould, The Cinquecento at Venice. Two Crises, Space, „Apollo” 1972, no. 95, s. 381.

${ }_{15}$ Por. P. Fortini Brown, Venetian Narrative Painting in the Age of Carpaccio, New Haven-London 1988, s. 219-234. 


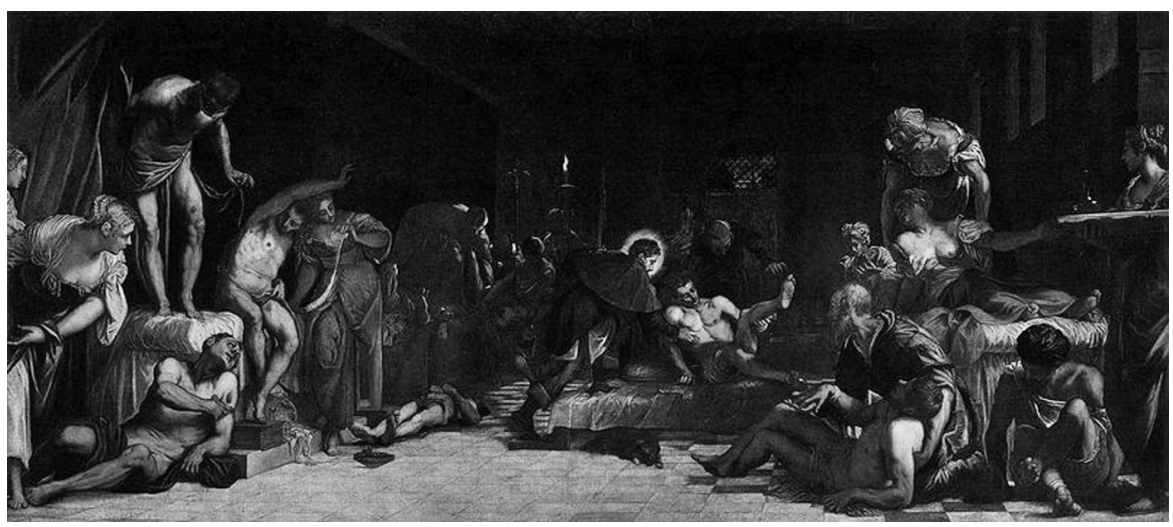

Nieco inaczej przedstawia się zjawiskowa postać znajdująca się obok św. Rocha, która ma charakterystyczny turban na głowie. W weneckim malarstwie XVI w. ów element nakrycia głowy był kojarzony ze światem kultury orientalnej. Podczas gdy ze spiczastymi nakryciami głowy na renesansowych obrazach weneckich identyfikowano Żydów, turbany nosili zwykle Turcy ${ }^{16}$. Postać z siwiejącą brodą wydaje się najstarsza w gronie konsylium, lecz jednocześnie najbardziej bezradna. Malarz nie przedstawił dłoni tej postaci, a zatem nie może ona wykonać żadnego gestu. $\mathrm{Z}$ jednej strony to bardzo kontrastuje $\mathrm{z}$ wyrazistymi gestami dwóch pozostałych członków konsylium i sugeruje, że dłonie orientalnej postaci są bezużyteczne.

Na marginesie obrazu znajduje się jeszcze jedna osoba w turbanie. Siedzi na ziemi ze skrzyżowanymi „po turecku” nogami. To jedyny $\mathrm{z}$ chorych, któremu nie towarzyszy nikt, kto mógłby mu pomóc. Został on wykluczony z kręgu chrześcijańskiej caritas, której okazywanie wobec ciała należało do statutowych obowiązków każdej konfraterni. Postać ta ma krótkie spodnie, które zasłaniają uda. Przy takim stanie rzeczy wczesne rozpoznanie choroby wydawało się niemożliwe, gdyż to właśnie od wewnętrznej strony uda można było najszybciej zdiagnozować dżumę. Najczęściej spotykane wyobrażenia świętego Rocha ukazują go frontalnie z obnażoną raną na udzie ${ }^{17}$. Niemniej jednak ani

${ }^{16}$ A. Gentili, Le storie di Carpaccio. Venezia, Turchi, gli Ebrei, Venezia 1996; B. Blumenkranz, Il cappello a punta. Ebreo medievale nello specchio dell'arte christiana, Ch. Frugoni (red.), Roma 2003; A. Gentili, Vedere i miracoli. Politiche della guarigione in Tintoretto e Veronese, [w:] Bilancia dell'Arcangelo: vedere i dettagli nella pittura veneziana del Cinquecento, Roma 2009, s. 199-214.

${ }^{17}$ L. Réau, hasło: Roch de Montpellier, [w:] tenże, Iconographi de l'art chrétien, p. III, vol. 3, Paris 1959, s. 1155-1161; K. Welker, hasło: Rochus, [w:] Lexikon der christlichen Ikonographi, E. Kirschbaum (red.) i in., Bd. 8, Rom-Freiburg-Basel-Wien 1976, s. 275-278; D. Rigaux, Le dossier iconogrsphique de saint Roch: nouvelles images, nou- 
tradycja hagiograficzna, ani tym bardziej ikonograficzna nie pozwalają na wyjaśnienie, dlaczego na obrazie Tintoretta św. Rochowi towarzyszy postać w turbanie ${ }^{18}$.

Maria Elena Massimi wykazała, że w roku 1549, kiedy to powstał obraz Tintoretta, bractwo od dłuższego czasu zaangażowane było $\mathrm{w}$ powołanie tzw. ospedaletto, czyli niewielkiego szpitala-hospicjum dla najuboższych członków konfraterni ${ }^{19}$. $\mathrm{Z}$ różnych względów jednak do powołania hospicjum nie doszło. Według XVI-wiecznej krytyki weneckich bractw, zdarzało się często, że gwardianie konfraterni woleli zabiegać o splendor własnej siedziby niż o statutowe cele, do których należała troska o najuboższych ${ }^{20}$. Rada Dziesięciu, jako organ nadzorujący z ramienia Republiki działalność konfraterni, wielokrotnie i bezskutecznie usiłowała ograniczyć marnotrawstwo charytatywnych instytucji, powołując się na prawa przeciwko zbytkowi.

Ostatnie badania nad dziejami rezydencji konfraterni św. Rocha pokazały, że w latach 20. i 30. XVI w., kiedy wznoszono budowlę, część członków opowiadała się za bardzo okazałą, reprezentacyjną inwestycją, natomiast inni, hołdujący ideałom republikańskiej mediocritas, woleli skromniejsze rozwiązania ${ }^{21}$. Bractwo św. Rocha powstało dopiero pod koniec XV w., ale bardzo szybko stało się najbardziej wpływowym wśród innych wielkich bractw zwanych scuole gran$d i^{22}$. Zapewne przyczyniły się do tego relikwie św. Rocha, należące

velle chronologie, [w:] San Rocco. Genesi e prima espansione di un culto, A. Rigon, A. Vauchez (red.), Bruxelles 2006, s. 245-268.

${ }_{18}$ A. Niero, San Rocco. Storia-leggenda-culto, Vicenza 1991; San Rocco. Genesi e prima espansione..., dz. cyt., passim.

${ }_{19}$ M.E. Massimi, Tintoretto e i confratelli..., dz. cyt., s. 74-79.

${ }^{20}$ Jednym z najbardziej znanych krytyków był jubiler i poeta zarazem - Alessandro Caravia (1503-1566). E. Benini Clementi, Riforma religiosa e poesia popolare a Venezia nel Cinquecento: Alessandro Caravia, Firenze 2000; G. Köster, Venerable tradition or reprehensible luxury? A scandal about processional display in the Scuola Grande di san Rocco, „Confraternitas” 2010, no. 21, s. 31-42.

${ }^{21}$ G. Guidarelli, Architecture and Charity. Paradoxes and Conflicts in the Construction of the Scuola Grande di San Rocco in Venice (1517-1560), „Confraternitas” 2010, no. 21 , s. $17-30$.

${ }^{22}$ Literatura przedmiotu na temat weneckich bractw jest bardzo obszerna. Na temat funkcji społecznych weneckich konfraterni nadal pozostaje aktualna monografia B. Pullana, Rich and poor in Renaissance Venice: the social institutions of a catholic state to 1620, Cambridge 1971. Por. tenże, The Scuole Grandi of Venice. Some Further Thoughts, [w:] Christianity and the Renaissance, T. Verdon, J. Henderson (red.), Syracuse-New York 1990, s. 271-301. Odnośnie do wpływów reformacji na weneckie bractwa: tenże, Le Scuole grandi e la loro opera nel quadro della Controriforma, „Studi Veneziani" 1972, no. 14, s. 83-109. Na temat dekoracji wnętrz konfraterni zob.: P. Fortini Brown, dz. cyt.; G. Köster, Künstler und ihre Brüder. Maler, Bildhauer und Architekten in den venezianischen Scuole Grandi (bis ca. 1600), Berlin 2008; na temat bractwa 
Jacopo Tintoretto i Vettore Trincavella - malarz i lekarz...

do bractwa od ok. 1483 r., kiedy to pojawiły się w Wenecji pierwsze symptomy kolejnej epidemii dżumy ${ }^{23}$. Nowa konfraternia zyskiwała członków, wśród których znaleźli się przedstawiciele najbogatszych mieszczańskich rodzin. Status ekonomiczno-społeczny przedstawicieli konfraterni przekładał się nie tylko na wpływy bractwa na politykę wewnętrzną samej Wenecji, ale także na politykę międzynarodową. Na przykład z testamentu Bonadia Maruciniego, który wraz z bratem Benedetto tworzył w konfraterni klan sprzyjający Tintoretto, dowiadujemy się, że stać go było na udzielanie kredytu nawet królowi Filipowi $\mathrm{II}^{24}$.

O prestiżu bractwa św. Rocha, jak również o celowości powołania szpitala, nowego ośrodka taumaturgii ciała $i$ duszy, mógł decydować także poziom wiedzy medycznej niektórych lekarzy należących do bractwa. 20 marca 1532 r. dwaj członkowie konfraterni św. Rocha w obecności serenissimo principe Andrei Grittiego oraz kilku patrycjuszy nadzorujących pracę weneckiego kolegium medycznego stoczyli w Pałacu Dożów publiczną debatę ${ }^{25}$. Dyskusja, która poprzedzona była sporami w siedzibie kolegium, odbyła się między dwoma lekarzami - Valeriem Superchiem i Vettorem Trincavellą ${ }^{26}$. Obu oponentom, jak było to w ówczesnym zwyczaju, towarzyszyli dwaj inni lekarze - Marino Broccardo oraz Dona di Muti. Na pozór debata dotyczyła szczegółowego zagadnienia farmaceutycznego, które u progu nowożytności interesowało także polityków, a mianowicie trucizn i stosownego antidotum ${ }^{27}$. Vettor Trincavella uważał, że należy dokonać dokładnych, nowych tłumaczeń tekstów Galena odnoszących się do tego problemu, aby móc znaleźć użyteczne rozwiązanie. Natomiast Velerio Superchio był zdania, że wystarczy tradycja, która wynikała z tłumaczeń dokonanych w średniowieczu przez autorów arabskich ${ }^{28}$.

św. Rocha zob.: La Scuola Grande di San Rocco a Venezia, F. Posocco, S. Settis (red.), Modena 2008.

${ }^{23} \mathrm{~W}$ Wenecji w 1478 r. miało umrzeć 30 tys. mieszkańców. Kolejna epidemia przyczyniła się do powstania pierwszej obszernej biografii świętego patrona zadżumionych. Jej autorem był wenecki patrycjusz Francesco Diedo. Zob.: P. Ascagni, dz. cyt.; por. G. Tournoy, Francesco Diedo, Venetian humanist and politician of the Quattrocento, „Humanistica Lovaniensia” 1970, no. 19, s. 201-234; P. Bolle, Saint Roch, una question de méthodologie, [w:] San Rocco. Genesi e prima espansione..., dz. cyt., s. 9-56.

${ }^{24}$ M.E. Massimi, dz. cyt., s. 19.

${ }^{25}$ M. Sanuto, I Diari, Venezia 1900, vol. 55, s. 657. Sanuto zgodnie z kalendarzem weneckim podaje rok 1532 .

${ }^{26}$ Tamże, s. 648 i 654.

${ }_{27}$ Zob. A. Pastore, Veleno. Credenze, crimini, saperi nell'Italia moderna, Bologna 2010.

${ }^{28}$ G. Degli Agostini, Notizie istorico-critiche intorno la vita e le opere degli scrittori veneziani, Venezia 1752-1754 (reprint: Bologna, 1975), vol. II, s. 530-531. Większość 
Z innych, lepiej udokumentowanych dyskusji o analogicznym charakterze wiemy, iż w rzeczywistości chodziło o bardziej ogólny problem dotyczący humanistycznej debaty nad wartością scholastycznej, a zatem akademickiej tradycji wobec rodzącego się empiryzmu, który niekiedy, jak np. u Paracelsusa, mógł sprzyjać rozwojowi alchemii i magii. Debatę zainicjował wykształcony na padewskim, a zatem znajdującym się pod weneckim nadzorem uniwersytecie Niccolò Leoniceno (1428-1524) ${ }^{29}$. Większość życia spędził on w Ferrarze, gdzie nauczał matematyki, filozofii i medycyny, ale zasłynął przede wszystkim jako znawca greki. Zapewne nie jest też przypadkiem, że doskonała znajomość greckiego przyczyniała się do nadania Trincavellemu pseudonimu Il $\mathrm{Greco}^{30}$. Wraz z synem Zun Franco, który również był lekarzem, stali się nie tylko wydawcami oryginalnych tekstów greckich odnoszących się do zagadnień medycznych, ale także tłumaczami prac filozoficznych z greki na łacinę ${ }^{31}$. Humanistyczna dbałość filologiczna wynikająca $\mathrm{z}$ odkrycia oryginalnych greckich tekstów spowodowała, że zarówno Leoniceno, jak i Trincavella uznali nadrzędną rolę greckiej, pierwotnej medycyny wobec średniowiecznych jej interpretacji dokonanej przez arabskich tłumaczy. Tym samym mogli kwestionować dorobek uniwersyteckiej scholastyki i otworzyć się na rodzaj empirycznego, osobistego doświadczenia w badaniach medycznych ${ }^{32}$.

Leoniceno był przekonany o konieczności powrotu do oryginałów greckich ze względu na odnalezienie botanicznych nieścisłości u Pliniusza. I to właśnie błędy Pliniusza, a zatem rzymskiego autora, stały się punktem wyjścia querrelli między Leoniceno a liczną rzeszą tak wybitnych humanistów, jak np. Poliziano. Niektórzy, odpowiadając na

informacji biograficznych Degli Agostini zaczerpnął z wprowadzenia do wydania dzieł Trincavellego, którego dokonał uczeń lekarza Lorenzo Marucini w 1586 r. Por. Victoris Trincavelli veneti philosophi ac medici clarissimi et in celeberrima patavina academia olim primari professori omnia opera, Lugundi MDLXXXVI, k. 7-9 [numeracja własna]. Na temat wcześniejszych publikacji V. Trincavellego zob.: M. Sicherl, Die griechischen Erstausgaben des Vettore Trincavelli, Paderborn-Wien 1993; L. Perini, La vita e i tempi di Pietro Perna, Roma 2002, s. 292-293, 316, 318-319.

${ }^{29}$ L.A. Piras, Le dispute filologiche sulla Naturalis Historia di Plinio il Vecchio, Cum Barbaris Decertare. Sull'Umanesimo medico di Niccolò Leoniceno e sulla sua controversia col Poliziano, „Schifanoia” 2016, no. 50-51, s. 169-176. Na temat Nicolò Leonicena zob.: D. Mugnai Carrara, La biblioteca di Nicolò Leoniceno. Tra Aristotele e Galeno: cultura e libri di un medico umanista, Studi, vol. 66, Firenze 1991, s. 13-102.

${ }^{30}$ G. Degli Agostini, dz. cyt., s. 530. Na temat tłumaczeń greckich Tricavello zob.: M. Sicherl, dz. cyt.

31 Tamże.

${ }^{32}$ H. Hirai, Medical Humanism and Natural Philosophy. Renaissance debates on Matter, Life, and the Soul, Series: Medieval and early modern science, vol. 17, Leiden 2011. 
krytykę Leoniceno, zarzucili mu, że usiłuje jeden autorytet zastąpić innym, a nie, jak twierdził, oprzeć wiedzę medyczną przede wszystkim na bezpośredniej obserwacji. Jeśli przyjrzeć się jednak praxis Trincavellego, można przypuścić, że podobne zarzuty wobec zwolenników greckiego puryzmu są bezpodstawne. Wenecki lekarz zasłynął $\mathrm{z}$ tego, że zabierał swych uczniów na wizyty do chorych, aby nabierali bezpośredniego i osobistego doświadczenia w diagnostyce. W XVI w. aż 600 studentów decydowało się na uzyskanie stopnia doktorskiego w Wenecji, która musiała sprostać zarówno konkurencji, jak i autorytetowi uniwersytetu padewskiego ${ }^{33}$. 232-osobowa grupa studentów broniła prace dyplomowe w latach 1545-1562, kiedy największe wpływy w kolegium miał Trincavella. Został on wybrany promotorem przez 155 adeptów medycyny, co najlepiej świadczy o tym, że studenci doceniali jego sposób postępowania. Trincavella okazał swoją niechęć wobec uniwersyteckich apanaży w 1551 r., gdy przyszło mu objąć katedrę medycyny na padewskim uniwersytecie. Reformatorzy padewskiego ateneum: przyszły doża Nicolo da Ponte oraz wpływowy patrycjusz Matteo Dandolo przekonywali uczonego do podjęcia tychże obowiązków ${ }^{34}$. Trincavella uległ w końcu ich perswazjom, jednakże nigdy nie stał się członkiem padewskiego kolegium medycznego. $\mathrm{W}$ ostatecznym przyjęciu propozycji pomogła lekarzowi pespektywa powstania w Padwie ogrodu botanicznego, laboratorium koniecznego dla farmaceutycznych eksperymentów, które stały się przedmiotem dyskusji z 1532 r. Wspomniany wcześniej syn Vettora, Zuan Franco, został jednym z głównych organizatorów tego laboratorium ${ }^{35}$. Nie bez znaczenia było też poprawienie uposażenia nowego profesora padewskiej katedry. Nie należy jednak przeceniać tego ostatniego argumentu. W swym testamencie Vettor Trincavella przyznawał, że za jego umiejętnościami i osiągnięciami krył się zbiorowy wysiłek całej rodziny ${ }^{36}$. Zwłaszcza samotny brat Vincenzo, który był kupcem, został w sposób szczególny polecony przez Vettora trosce dzieci. Wzorem

33 Dane statystyczne zostały zaczerpnięte $\mathrm{z}$ osiemnastowiecznego manuskryptu przechowywanego w Biblioteca Universitaria di Padova, Ms. 318, k. 57-60; por. R. Palmer, The Studio of Venice and its graduates in the sixteenth century, Trieste 1983, Contributi alla storia dell'Università di Padova, vol. 12, s. 70.

${ }^{34}$ G. Gullino, hasła: Nicolò da Ponte i Matteo Dandolo, [w:] Dizionario Biografico degli Italiani, Roma 1986, vol. 32, http://www.treccani.it/enciclopedia (dostęp: 1.01.2018).

${ }^{35}$ V. Da Piaz, M. Rippa Bonati, L'Horto medicinale dello studium patavinum: progetto e rappresentazione, [w:] L'Orto botanico di Padova 1545-1995, A. Minelli (red.), Venezia 1995, s. 33.

${ }^{36}$ Archivio di Stato di Venezia, Notarile Testamenti, v. 1214, f. 1218. 
patrycjuszy także w mieszczańskich rodzinach weneckich często tylko jeden $\mathrm{z}$ braci wstępował $\mathrm{w}$ związek małżeński, aby nie dochodziło do podziału majątku, szczególnie nieruchomości. $Z$ tego powodu, zapewne, tylko starszy Vettore miał żonę i dzieci, które zobowiązał do opieki nad Vincenzem. Trudno w tym kontekście pominąć fakt, że Vincenzo Trincavella, pełniąc najwyższe rangą funkcje w konfraterni św. Rocha, usilnie zabiegał o powstanie wspomnianego wcześniej szpitala. Dla starszego brata byłoby to właściwe miejsce dla wykonywania praktyki zawodowej.

W opowieściach hagiograficznych o św. Rochu pojawia się imię Vincenzo jako „ordynatora” lazaretu, w którym przyszły święty miał dokonać uzdrowień zadżumionych ${ }^{37}$. Kiedy członkowie konfraterni św. Rocha patrzyli na obraz Tintoretta, mogli postrzegać tajemniczą postacią z bezradnie rozłożonymi dłońmi jako subtelną aluzję do gwardiana Vincenza Trincavella, który okazując swoją, lub szerzej, ludzką bezradność wobec cierpienia, pozostawiał chorego wstawienniczej mocy świętego.

Obraz św. Rocha w szpitalu stał się zatem wizualną reminiscencją niezrealizowanego projektu powstania szpitala, jak pisała Massimi ${ }^{38}$. Być może także upamiętnieniem debaty, która toczyła się wśród członków bractwa nad wyborem właściwej tradycji medycznej. Zjawiskowa, orientalna postać, wkraczająca między św. Rocha a Vincenzo, tego realnego czy też legendarnego, stanowi aluzję do ciężaru arabskiej tradycji, której magia autorytetu nie powinna była przeszkodzić wstawienniczej misji świętego.

Malarz w kaplicy prezbiterium nie mógł w sposób oczywisty dla każdego przedstawić zaistniałego wśród braci konfliktu, ale uczynił to w sposób aluzyjny. Zresztą np. w kwestii nadawania przewagi doświadczeniu nad autorytetem w rzeczywistości Superchio zgadzał się z Trincavellem. Obaj utrzymywali, że zasadniczą wartością weneckiego kolegium medycznego, która decydowała o jego przewadze nad innymi renesansowymi ośrodkami, była możliwość zbadania w ciągu tygodnia większej liczby przypadków zachorowań niż w innych placówkach w ciągu całego roku ${ }^{39}$. Superchio doceniał także możliwość teoretycznych dyskusji, które miały miejsce w Wenecji ${ }^{40}$.

Powstaje zatem pytanie, gdzie przebiegała krytyczna granica, która spowodowała, że jeden $\mathrm{z}$ weneckich medyków, członek tej samej

\footnotetext{
37 P. Ascagni, dz. cyt., s. 111-112.

38 M.E. Massimi, dz. cyt., s. 64-66.

${ }^{39}$ R. Palmer, dz. cyt., s. 44.

40 Tamże.
} 
konfraterni i tego samego kolegium medycznego, skłonny był zaufać średniowiecznej tradycji, natomiast inny gotów był ją kwestionować. Warto zwrócić uwagę na różnicę pokoleniową, która dzieliła obu lekarzy. Z testamentu Valeria Superchia wynika, że w 1540 r. kończył 70 lat, podczas kiedy Vettor Trincavella dopiero w roku 1562 miał 73 lata $^{41}$. Owa różnica pokoleniowa mogła przekładać się na stosunek do autorytetu tradycji, ale także na odmienny smak w rozumieniu reprezentacyjności swego stanu, a co za tym idzie - także tożsamości korporacyjnej.

Jak wspomniano wcześniej, badacze zajmujący się historią siedziby konfraterni św. Rocha wyróżnili istnienie wewnątrz bractwa dwóch stronnictw ${ }^{42}$. Jedno $\mathrm{z}$ nich skupione było wokół zamożnego kupca Francesca di Giovanniego, który zajmował się handlem jedwabiem i uważał, że siedziba bractwa winna być jak najbardziej okazała. Natomiast drugie stronnictwo reprezentował starszy Bartolomeo Marin. Należał on do pierwszego pokolenia powstałego zaledwie w 1478 r. bractwa. Pozostałe cztery scuole grandi tworzone były w XIII i XIV w.

Czas największej aktywności Francesca di Giovanniego przypadł na lata 20. XVI w., kiedy udało mu się doprowadzić do zwolnienia ze stanowiska głównego architekta konfraterni Bartolomea Bona. Na jego miejsce zatrudniony został Scarpagnino, który jako uczeń Francesca Sansovina należał w swym czasie do najbardziej wziętych mistrzów, zainteresowanych realizacją jedynie ambitnych projektów. W efekcie siedzibę bractwa wyposażano $\mathrm{w}$ bardzo kosztowną klatkę schodową zwaną imperialną, której nie miała żadna inna budowla wenecka. Jej realizacja wymusiła przebudowę całej struktury, którą pierwszy architekt Bartolomeo Bon modelował na tradycyjnych, znacznie mniej okazałych wzorach. Bartolomeo Marin był zwolennikiem pierwotnych planów siedziby bractwa.

W prezbiterium kościoła, a zatem dokładnie w tym samym miejscu, gdzie Tintoretto namalował dla konfraterni swój pierwszy obraz przedstawiający św. Rocha w lazarecie, Bartolomeo Marin ufundował dla siebie i swych następców grobowiec. Jeszcze jego syn Bernardo Marin w swym testamencie pisał: „I pragnę, aby ciało moje spoczęło w kościele św. Rocha w kaplicy i grobowcu, gdzie zostały złożone kości moich przodków. Ta kaplica przynależy do domu [rodziny] Marin"43.

${ }^{41}$ Por. Archivio di Stato di Venezia, Notarile Testamenti, v. 191, f. 672; v. 1214, f. 1218.

${ }^{42}$ G. Guidarelli, dz. cyt.

${ }^{43}$ Por. Archivio di Stato Venezia, San Lorenzo. Atti, v. 2, f. 2. 
O ile przy wznoszeniu siedziby konfraterni św. Rocha zwyciężyło stronnictwo przychylne bardziej okazałemu projektowi, o tyle o dekoracji jego wnętrza zdecydowali zapewne członkowie konfraterni preferujący skromniejsze rozwiązania, kulturowo związani z Bartolomeem Bonem oraz Bartolomeem Marinem. W konsekwencji można zasugerować, że konflikt między stronnictwami wewnątrz bractwa przesądził o ostatecznym zwycięstwie Tintoretta w pracach dekoracyjnych zarówno dla kościoła św. Rocha, jak i znajdującej się obok siedziby konfraterni.

Mimo że - jak wielokrotnie było wspomniane - w 1549 r. Tintoretto namalował opisany wyżej obraz, a dziesięć lat później wykonał odrzwia szafy relikwiarzowej, na których znalazło się przedstawienie Chrystusa uzdrawiającego nad sadzawką Betesda, to dopiero w 1565 r. przyznano mu prawo do wykonania całego cyklu obrazów w samej siedzibie św. Rocha. W tym właśnie czasie malarz stał się też pełnoprawnym członkiem konfraterni, dla której pracował przez kolejne 20 lat. W siedzibie konfraterni pozostawił jeden z najważniejszych cykli malarskich drugiej połowy XVI w.

W 1564 r., kiedy zarząd bractwa zdecydował się na rozpisanie konkursu na obraz Glorii św. Rocha do sali posiedzeń zarządu bractwa, jeden z członków konfraterni zadeklarował, że gotów jest zapłacić 15 dukatów, aby wykonawcą projektu nie został Jacopo Tintoretto. Była to kwota trzykrotnie wyższa od tej, którą zadeklarowali inni. Wiemy, że pretensje do pracy w konfraterni zgłaszał Tycjan. Stworzył on dla bractwa nie tylko wspomniany wcześniej obraz Chrystusa niosącego krzyż, który wielu uważało za cudowny, a przez to przynoszący bractwu znaczne zyski, lecz także popularną rycinę przedstawiającą św. Rocha. Pielgrzymi przybywający do sanktuarium mogli nabywać i zabierać ze sobą reprodukcje tego przedstawienia. Wszystko, co sprzyjało rozwojowi kultu świętego, przyczyniało się także do wzbogacania bractwa. Zatem pretensje Tycjana do dekorowania konfraterni były jak najbardziej uzasadnione. W czasie kiedy powstawała okazała siedziba bractwa, Tycjan stał się oficjalnym malarzem republiki weneckiej, którym pozostał do końca życia. Niemniej jednak kiedy pod koniec lat 30. w Wenecji zaczął działać warsztat Tintoretta, Tycjan pomału tracił zamówienia w swej ojczyźnie $\mathrm{z}$ adopcji ${ }^{44}$. Jak sam podkreślał, co prawda nieco z przesadą, monopol na jego dzieła stopniowo zaczęły posiadać dwory, najpierw Karola V, a później Filipa $\mathrm{II}^{45}$. W praktyce zatem, będąc oficjalnym malarzem republiki, stawał się artystą dworu.

\footnotetext{
${ }^{44}$ A. Gentili, Tiziano, Milano 2012.

45 Tenże, Da Tiziano a Tiziano, Roma 1988, s. 254.
} 
Powyższe uwagi mogą się wydawać zbyt daleko odbiegające od tematu niniejszego tekstu. Okazują się jednak nieodzowne dla zrozumienia konfliktu pokoleniowego między Valeriem Superchiem a Vettorem Trincavellą $\mathrm{w}$ kwestii smaku, który nie miał znaczenia dla ich praktyki lekarskiej, ale przekładał się na rozumienie autorytetu i tradycji.

Z niektórych szczegółów testamentu Valeria Superchia, o których dotychczas nie wspominałam, wynika, że jego najstarszy syn Hieronim przebywał na służbie u kardynała Pietra Bemba (1470-1547) ${ }^{46}$. Słynął on ze swej dworskiej kultury. Był to jeden z humanistów bliskich Tycjanowi, który wykonał znany portret kardynała. Superchio powierzył Bembie przygotowanie tekstu epitafium na swój grób w kościele Santa Maria dei Servi.

Zachowane dokumenty wskazują, że Vettor Trincavella był również związany z ważnym hierarchą Kościoła katolickiego, biskupem Bergamo Vittorem Soranzo ${ }^{47}$. Niemniej jednak nic nie wskazuje na to, by relacja ta w jakikolwiek sposób wykraczała poza kontakty zawodowe. Soranzo był podejrzewany przez Inkwizycję o sympatie filoprotestanckie. Trincavella, wydając orzeczenia o złym stanie zdrowia, kilkakrotnie usprawiedliwił niemożność stawienia się biskupa w Rzymie. Jednak $\mathrm{w}$ testamencie lekarza nie ma żadnej wzmianki o jego znajomości ze zmarłym w $1558 \mathrm{r}$. biskupem. Jedyną troską lekarza wydaje się los dzieci, a zwłaszcza córek, które były żonami wpływowych urzędników weneckich, oraz los brata Vincenza.

Podsumowując, idąc tropem myśli klasycznej już książki Hansa Beltinga Obraz i kult, przedstawienie Tintoretta ukazujące św. Rocha w lazarecie można uznać za obraz graniczny między epoką kultu obrazu a epoką sztuki ${ }^{48}$. Obrazy Tycjana, nawet jeżeli nie zawsze były obrazami kultowymi w tradycyjnym znaczeniu, to jednak pozostawały obrazami kontemplacyjnymi w sferze operowania kolorem i światłem $^{49}$. Przedstawiania Tintoretta miały bardziej analityczny charakter, który Tycjan zachował dla swych rycin ilustrujących anatomiczny traktat Andrei Vesaliusa ${ }^{50}$.

\footnotetext{
${ }^{46}$ Pietro Bembo e le arti, G. Beltramini (red.) i in., Venezia 2013.

${ }^{47}$ M. Firpo, Vittore Soranzo vescovo ed eretico, Bari-Roma 2006.

${ }^{48} \mathrm{H}$. Belting, Obraz i kult. Historia obrazu przed epoka sztuki, tłum. T. Zatorski, Gdańsk 2010.

${ }^{49} \mathrm{M}$. di Monte, La morte è bella..., dz. cyt.

${ }_{50}$ Tiziano e la silografia veneziana del Cinquecento [kat. wystawy], M. Muraro, D. Ronsand (red.), Vicenza 1976; M. Muraro, Tiziano e le anatomie del Vesalio, [w:] Tiziano e Venezia, N. Pozza (red.), Vicenza 1980, s. 307-316.
} 


\section{Summary \\ Jacopo Tintoretto and Vittore Trincavello - painter and physician in the Saint Roch brotherhood in Venice}

Hospital interiors were presented in paintings for the first time in modern art in 1549, namely by Jacopo Robusti also known as Tintoretto. The painting St Roch in the Hospital is still hanging in the presbytery of the Saint Roch church in Venice. Contemporary historiography has determined that this innovative iconography of representation constituted a direct reference to efforts of the Confraternity Scuola Grande di San Rocco Rocco to have a hospice established. The goal of this paper is to connect the presence of oriental figures on the painting with the public debate between the members of the confraternity and physicians at the same time - Valerio Superchio and Vittore Trincavello.

Keywords: Tintoretto; Trincavello; renaissance medicine; Saint Roch confraternity 